\title{
Biofilm susceptibility to bacteriophage attack: the role of phage-borne polysaccharide depolymerase
}

\author{
Kevin A. Hughes, ${ }^{1}$ Ian W. Sutherland ${ }^{2}$ and Martin V. Jones ${ }^{3}$ \\ Author for correspondence: Kevin A. Hughes. Tel: +44 1223 221400. Fax: +44 1223362616. \\ e-mail:k.hughes@bas.ac.uk
}

1 British Antarctic Survey, High Cross, Madingley Road, Cambridge CB3 OET, UK

2 Institute of Cell and Molecular Biology, The University of Edinburgh, Daniel Rutherford Building, King's Buildings, Mayfield Road, Edinburgh EH9 3JH, UK

3 Unilever Research Laboratory, Port Sunlight, Quarry Road East, Bebington, Wirral L63 3JW, UK

\begin{abstract}
Biofilm bacteria Enterobacter agglomerans $53 \mathrm{~b}$ and Serratia marcescens Serr were isolated from a food processing factory. A bacteriophage (5F153b), which could infect and lyse strain 53b, was isolated from sewage. This has been shown to possess a polysaccharide depolymerase enzyme specific for the exopolysaccharide (EPS) of strain 53b. Using batch culture and chemostatlinked Modified Robbins Device systems it was observed that SF153b could degrade the EPS of a mono-species biofilm (strain 53b) and infect the cells. The disruption of the biofilm by phage was a combination of EPS degradation by the depolymerase and infection and subsequent cell lysis by the phage. Strain Serr biofilms were not susceptible to the phage and the biofilm EPS was not degraded by the phage glycanase, with the result that the biofilm was unaffected by the addition of SF153b phage. Scanning electron microscopy confirmed that specific phage could extensively degrade susceptible biofilms and continue to infect biofilm bacteria whilst EPS degradation was occurring.
\end{abstract}

Keywords: exopolysaccharide, biofilm, bacteriophage, virus, polysaccharide depolymerase

\section{INTRODUCTION}

Bacterial biofilms are found in the natural, industrial and medical environments and consist of microorganisms embedded in a glycocalyx that is predominantly composed of microbially produced exopolysaccharide (EPS) (Costerton et al., 1994). Biofilms are highly heterogeneous with structures such as streamers, water channels, stacks and fronds forming, depending on the prevailing conditions and environmental stresses (Keevil et al., 1995). The chemical, physical and structural nature of the polysaccharide also influences the properties of the polymer within the biofilm (Sutherland, 1995). The glycocalyx is of great importance to the bacteria as it may provide protection against environmental change, such as desiccation and antimicrobial agents, and may also act as a reservoir for nutrients and ions (Allison, 1993).

Bacteriophage are very common in the environment, with concentrations of $3.16 \times 10^{6}$ phage $\mathrm{ml}^{-1}$ being

Abbreviations: EPS, exopolysaccharide; MRD, Modified Robbins Device; $\mathrm{YE}$, yeast extract. detected in sewage samples (Ogunseitan et al., 1992). Evidence of the ability of bacteriophage-borne polysaccharide depolymerase enzymes to degrade bacterial polysaccharides has been recorded for over 40 years (Adams \& Park, 1956). Phage polysaccharide depolymerases are commonly observed in electron micrographs as spikes attached to the phage baseplate (Lindberg, 1977). In liquid culture, degradation of bacterial capsular material by phage-borne polysaccharide depolymerases occurs in a defined sequence (Fig. 1). The phage depolymerase binds to the capsular material (secondary receptor) and degrades the polymer until it reaches the cell surface where it binds to an outer-membrane receptor (primary receptor) and infects the bacterium. Bacterial lysis may occur or the phage may remain in a lysogenic state.

Relatively little information is available on the action of bacteriophage on biofilms (Doolittle et al., 1995, 1996) and even less on the action of bacteriophage-borne depolymerase enzymes on biofilm polysaccharides. As the majority of bacteria in the natural environment are thought to exist in biofilms the question of whether or not bacteriophage can penetrate the glycocalyx, infect the bacteria and degrade the biofilm is of great ecological 


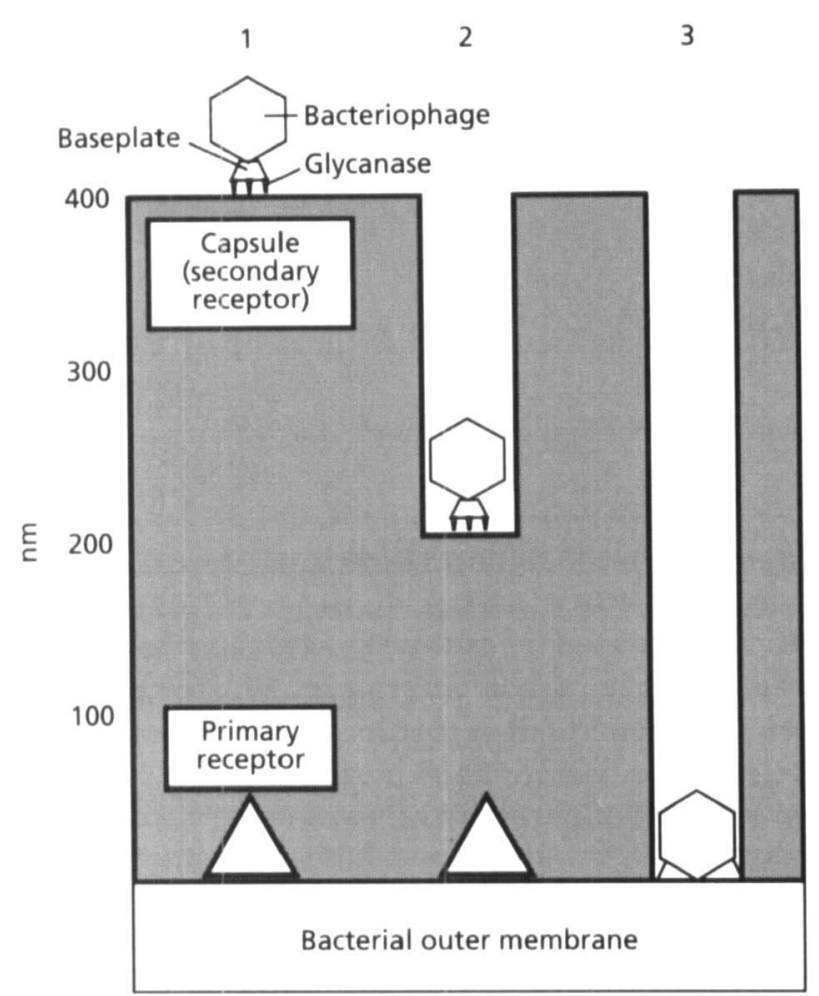

Fig. 1. Degradation of bacterial capsular polysaccharide by a phage-borne glycanase occurs in three stages. (1) Phage binds to capsular polysaccharide (secondary receptor). (2) Phageborne glycanase degrades polymer until phage reaches cell surface. (3) Phage binds to primary receptor and infects cell. Adapted from Lindberg (1977).

importance. Biofilm polysaccharide may normally protect the bacterial cells against the majority of bacteriophage (Weiner et al., 1995). However, if a phage possesses a specific polysaccharide depolymerase it may be able to degrade its way through the biofilm EPS and gain access to the bacterial surfaces. Consequently, it could cause biofilm disruption through cell infection and lysis, as well as EPS degradation. Phage glycanases are very specific. Small alterations in polymer composition or structure make them insusceptible to the depolymerase (Reiger-Hug \& Stirm, 1981).

Phage have been used to degrade biofilms before, but there has been little research on the influence of phageborne glycanases. Roy et al. (1993) studied the action of a quaternary ammonium compound and three Listeriaphage strains on Listeria monocytogenes which had been air-dried onto stainless steel and polypropylene surfaces. Hibma et al. (1997) studied the infection and removal of L-forms of Listeria monocytogenes with bacteriophage and lactic acid. Doolittle et al. (1995) grew Escherichia coli biofilms on polyvinylchloride coupons in a Modified Robbins Device (MRD) and infected them with bacteriophage $\mathrm{T}_{4} \mathrm{D}^{+}$. They showed that bacteriophage could infect a biofilm and suggested that the bacteria are not protected against bacteriophage by EPS as was previously suggested (Costerton et al., 1987). However, no mention was given of the mechanism by which the phage penetrated the biofilm EPS, nor whether a polysaccharide depolymerase was present. The objective of the present study was to elucidate the role of polysaccharide depolymerases in bacteriophage attack on biofilms.

\section{METHODS}

Media. Yeast extract medium (YE) with $2 \%(\mathrm{w} / \mathrm{v})$ glucose was routinely used (Sutherland \& Wilkinson, 1965). A concentrated glucose solution was autoclaved separately and added to the YE just before inoculation. Sloppy agar was prepared with $\mathrm{YE}$ and $5 \mathrm{~g}$ agar $\mathrm{l}^{-1}$. For chemostat studies 0.1 $\times$ YE was used (diluted with distilled water). Serial dilutions were made with PBS ( $\mathrm{g}$ per litre distilled water: $\left.\mathrm{NaCl}, 8 \cdot 0 ; \mathrm{K}_{2} \mathrm{HPO}_{4}, 1 \cdot 21 ; \mathrm{KH}_{2} \mathrm{PO}_{4}, 0 \cdot 34\right)$.

Phage. Bacteriophage SF153b was isolated from sewage obtained from the local municipal sewage works at Seafield, Edinburgh (Hughes et al., 1998).

Bacteria. Enterobacter agglomerans $53 \mathrm{~b}$ and Serratia marcescens Serr are biofilm-forming strains isolated from a food processing plant and characterized using the API $20 \mathrm{E}$ system (Dr M. V. Jones, Unilever Reseach Laboratory, Port Sunlight). M53b was a phage-resistant mutant derived from strain $53 \mathrm{~b}$.

Production of phage-resistant mutant of strain 53b (M53b). A culture of strain $53 \mathrm{~b}$ was grown up to mid-exponential phase in $100 \mathrm{ml}$ YE. High titre phage $(5 \mathrm{ml})$ suspension was added to the bacterial culture to ensure that the vast majority of bacteria were infected by phage. The $\mathrm{OD}_{600}$ of the culture was monitored until after bacterial lysis and phage progeny release had occurred. The flask contents were sampled and streaked out on agar plates to give single bacterial colonies. The plates were incubated overnight at $30^{\circ} \mathrm{C}$. Any colonies that developed either were phage-resistant or were not infected by the phage. As the culture was infected with a very high phage titre, the chances of having uninfected bacterial cells was low. To confirm that a specific single colony was phage-resistant, the process of bacterial cell growth to mid-exponential phase and addition of phage was repeated. No fall in optical density was observed after the addition of phage, indicating that the bacteria were phage-resistant. This was again confirmed by spotting $100 \mu \mathrm{l}$ aliquots of phage suspension onto a freshly spread lawn of the phage-resistant bacteria. After incubation, no plaques were seen, confirming that the bacterium was indeed phage-resistant. However, areas of decapsulated bacteria were observed where the phage suspension was added, indicating that M53b EPS was susceptible to the phage polysaccharide depolymerase. Purified M53b EPS was subjected to degradation by phage depolymerase (using the method of Hughes et al., 1998) and was found to be readily degraded.

\section{Bacteriophage lysate and polysaccharide depolymerase}

Production of high titre crude phage suspension. To $500 \mathrm{ml}$ of a mid-exponential phase strain $53 \mathrm{~b}$ culture $1 \mathrm{ml} \mathrm{SF} 153 \mathrm{~b}$ phage suspension was added. The $\mathrm{OD}_{600}$ of the culture was monitored. A fall in optical density, due to cell lysis, indicated replication of the infectious phage. The phage were separated from most bacterial cell debris by centrifugation at $21000 \mathrm{~g}$ $(8 \times 50 \mathrm{ml}$ tubes $)$ for $20 \mathrm{~min}$. The supernatant was dialysed 
against distilled water for $48 \mathrm{~h}$ to remove low molecular mass material, including glucose, then concentrated against PEG 6000 for $16 \mathrm{~h}$ at $4^{\circ} \mathrm{C}$. The supernatant (containing phage particles, phage components and the contents of the lysed bacterial cells) was collected then filtered to remove surviving or intact bacterial cells (Millipore, $0.45 \mu \mathrm{m}$ pore size). The crude phage lysate was stored at $4{ }^{\circ} \mathrm{C}$ and used as soon as possible.

Separation of phage lysate into phage particles and soluble enzyme. The concentrated phage lysate was centrifuged at $21000 \mathrm{~g}$ for $20 \mathrm{~min}$, then the supernatant was ultracentrifuged at $100000 \mathrm{~g}$ for $3 \mathrm{~h}$ (Sorvall OTD65B ultracentrifuge and A841 rotor, $8 \times 36 \mathrm{ml}$ tubes) to separate soluble phage enzyme from phage particles. Drops $(100 \mu \mathrm{l})$ of the supernatant were dispensed onto a lawn of freshly spread strain $53 \mathrm{~b}$ bacteria. After incubation at $30^{\circ} \mathrm{C}$ for $16 \mathrm{~h}$, no plaques were seen on the plates, confirming that the supernatant was phage-free. However, extensive degradation of the bacterial EPS was observed. The phage-free supernatant, containing the soluble enzyme, was concentrated against PEG then frozen. The phage particles in the pellet were resuspended in distilled water with $0.01 \%$ azide and stored at $4{ }^{\circ} \mathrm{C}$.

\section{Biofilm production}

Flow-through MRD linked to a chemostat. The flow-through chemostat-linked MRD was used for biofilm production so that during the subsequent experiments on phage-biofilm interactions only adherent micro-organisms needed to be considered. The MRD was obtained from Biofilm Technologies Research Group, University of Exeter. It consisted of a long perspex tube with a lumen which was rectangular in cross-section. On one side of the tube were 25 circular ports which housed studs that positioned a test coupon flush with the internal surface of the MRD lumen. A bacterial culture could be passed through the lumen and a biofilm allowed to develop on the inside of the MRD and on the coupons. This biofilm was sampled by clamping the tubing at both ends of the MRD, removing a stud and its coupon and replacing it with a clean one. The coupon, still attached to the stud, was washed with $10 \mathrm{ml}$ PBS to remove any loosely adherent planktonic cells. The PBS was pipetted over the top of the stud and not directly onto the coupon surface to prevent biofilm damage (Jass \& Lappin-Scott, 1992).

A flow-through continuous culture system was assembled and attached to the MRD. YE $(0 \cdot 1 \times, 2 \%$ glucose $)$ was pumped into a $1 \mathrm{l}$ continuous culture vessel (Biotech) at a rate of $44 \mathrm{ml}$ $\mathrm{h}^{-1}$. The effluent liquid from the continuous culture vessel was passed through the MRD before being collected. Biofilms developed for $24 \mathrm{~h}$ and bacterial counts of $1.6 \times 10^{6}$ cells $\mathrm{cm}^{-2}$ on the MRD coupons were recorded. A ' $Y$ ' joint, placed just upstream of the MRD, allowed the attachment of a syringe for the sterile input of bacteriophage into the system once the system had been inoculated with bacteria. Clamps were used to stop back flow of bacteriophage into the continuous culture vessel when the bacteria in the MRD were being infected with phage. After addition of $20 \mathrm{ml}$ phage $\left(5.5 \times 10^{10}\right.$ plaqueforming units), infection was allowed to occur for $15 \mathrm{~min}$ before the phage suspension was washed out with sterile medium and liquid flow resumed. Samples of the biofilm within the MRD were taken at 15 and 30 min intervals and the number of adherent bacteria and phage measured. Effluent samples were also collected for phage and bacterial counts.

Enumeration of phage and bacteria on MRD coupons. After washing, the coupons were dislodged from the studs using a sterile scalpel and dropped into a universal bottle containing $10 \mathrm{ml} \mathrm{PBS}$. The coupon was vortexed for $1 \mathrm{~min}$ and samples were taken, serially diluted, plated onto YE plates and bacterial colonies were counted after $24 \mathrm{~h}$.

Where appropriate, the serial dilutions produced for measuring bacterial colony-forming units were also used to determine the number of phage on the coupons. The sloppy agar method was employed whereby $0 \cdot 1 \mathrm{ml}$ aliquots of the dilution series were plated out in $3 \mathrm{ml}$ sloppy agar to which $0.1 \mathrm{ml}$ mid-exponential-phase phage-susceptible bacteria had been added. After $24 \mathrm{~h}$ the plates were examined for plaques. Bacterial and phage counts were also determined for the effluent liquid by similar serial dilutions and plate counts. All bacterial plate counts and phage plaque counts were carried out in triplicate and the mean taken.

Tip box batch culture method. A batch culture method of growing biofilms on glass coverslips was developed which was simple to manufacture, sterilize and sample. The coverslips were $22 \times 22 \mathrm{~mm}$ (Laboratory Sales UK). The system involved the development of a stand that could support the glass coverslips and a culture vessel in which the stand would sit. The stand was composed of two parts, both made of $0.7 \mathrm{~mm}$ thick sheet stainless steel (Brown \& Glegg). The first part consisted of a series of 12 grooves in which the coverslips were supported vertically. The second part was a shallow walled tray, in which the first part sat, preventing the coverslips moving laterally out of the grooves. The culture vessel was made from a yellow tip box (Greiner, Labortechnik rack with 96 Gilson yellow prepacked tips). Once the rack for the tips was removed, the internal dimensions of the box (approx. $120 \times 83 \times 57 \mathrm{~mm}$ ) allowed the stand and coverslips to be placed inside. There was also room for a $25 \mathrm{~mm}$ magnetic flea which, once placed on a magnetic stirrer (120 r.p.m.), agitated the medium and allowed aeration. The tip box held $250 \mathrm{ml}$ medium and was incubated at $30^{\circ} \mathrm{C}$. After sealing the semitransparent tip box lid with autoclave tape, the whole system could be autoclaved. Glucose was autoclaved separately and added just prior to inoculation. Biofilms were generally grown up for $16 \mathrm{~h}$.

Enumeration of biofilm bacteria and phage on glass coverslips. Biofilm bacterial counts $\left(\mathrm{cm}^{-2}\right)$ could be estimated by crushing a coverslip in $5 \mathrm{ml}$ PBS, vortexing for $1 \mathrm{~min}$, serially diluting and plating out the suspended cells. Bacteriophage associated with the biofilm were counted using the sloppy agar method described above. As with the MRD experiment, all bacterial plate counts and phage plaque counts were carried out in triplicate and the mean taken. Each experiment was carried out at least three times.

Scanning electron microscopy (SEM) of phage interactions with bacterial biofilms. For SEM analysis, bacterial biofilms were grown up on $13.5 \times 0.155 \mathrm{~mm}$ glass discs (Agar Scientific) for $16 \mathrm{~h}$ with $2 \%$ glucose, using the tip box batch culture method. On removal the specimens were fixed by plunge freezing in liquid nitrogen. The discs were transferred at liquid nitrogen temperature to a Speedivac Pearse drying apparatus (Edwards High Vacuum Int.) at $-70^{\circ} \mathrm{C}$, which was then evacuated. The specimens were held under these conditions for $24 \mathrm{~h}$, then the temperature was gradually increased while maintaining the vacuum. This allowed total sublimation of ice from the specimens. The glass discs were mounted on SEM stubs (Agar Scientific) and the edges coated with silver dag (Agar Scientific) to increase conductivity from the top surface. The specimens were then gold-coated in an Emscope SC500a sputter coater (Agar Scientific) for $3 \mathrm{~min}$ at $20 \mathrm{~mA}$ and 0.08 
Torr $(10.64 \mathrm{~Pa})$. Examination of the specimens was on a Cambridge Stereoscan 250 SEM (LEO Electron Microscope). Pictures were taken on Kodak Tmax 100 film and processed in Kodak HC110 developer. Bacterial enumeration data were derived from at least three different images and the mean taken.

\section{RESULTS}

\section{Analysis of phage-biofilm interactions using a flow- through MRD linked to a chemostat}

On addition of the phage there was a rapid decline in the number of strain 53b biofilm bacteria on the MRD coupons compared to the control (Fig. 2). The number of phage on the coupons remained relatively constant at approximately $3 \times 10^{6} \mathrm{~cm}^{-2}$ until $3 \mathrm{~h}$ after the addition of the phage, when the phage count increased dra- matically. This may have been due to lysis of the bacterial cells and the release of new phage progeny. A similar increase in the number of phage was recorded in the effluent liquid that had passed through the MRD. The addition of phage reduced the biofilm population from over $1 \times 10^{6}$ to under $1 \times 10^{3}$ bacteria $\mathrm{cm}^{-2}$ in $5 \mathrm{~h}$.

\section{Examination of the effect of phage on biofilms grown in batch culture}

The tip box batch culture vessels were used in further studies instead of the MRD. A summary of the results produced using the batch culture system can be seen in Table 1.

Degradation of strain 53b biofilms by phage. Fig. 3 shows the infection and degradation of a biofilm by bac-

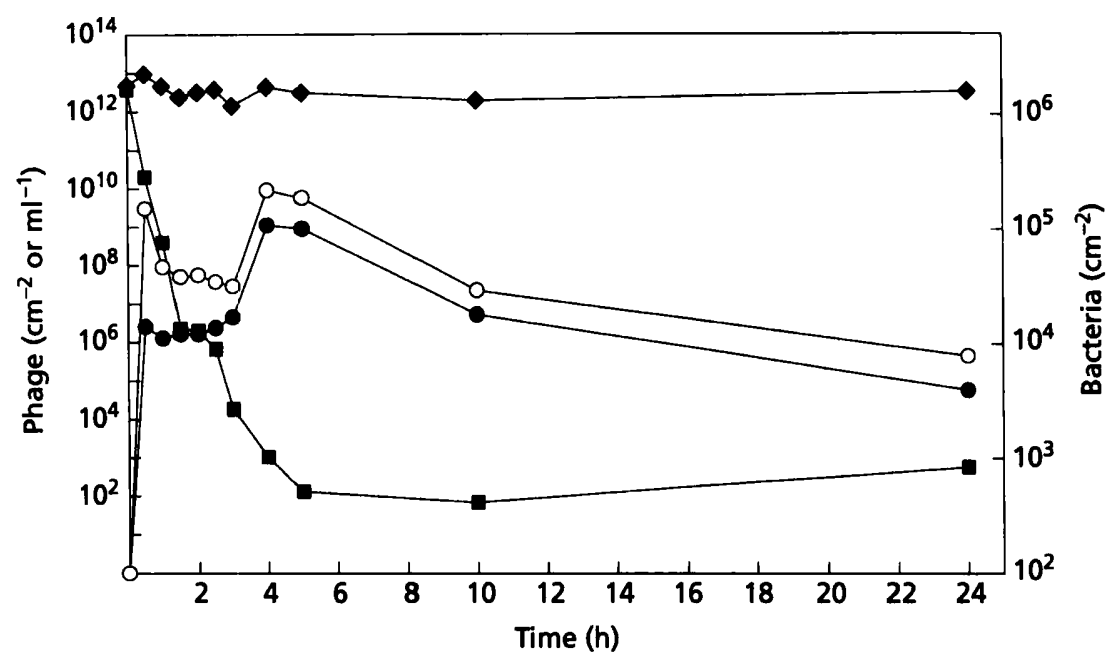

Fig. 2. Counts of adherent phage and bacteria on coupons of an MRD. An MRD was connected to a chemostat and supplied with inoculating microbes (strain 53b) and nutrients ( $0.1 \times$ YE, $2 \%$ glucose). The biofilm was allowed to develop for $24 \mathrm{~h}$ and then infected with phage. The number of phage and bacteria adhering to the coupons and the number of phage in the bulk fluid were monitored. $\square$, Biofilm bacteria $\left(\mathrm{cm}^{-2}\right) ; 0$, adherent phage $\left(\mathrm{cm}^{-2}\right) ; 0$, planktonic phage $\left(\mathrm{ml}^{-1}\right) ; \diamond$, biofilm bacteria $\left(\mathrm{cm}^{-2}\right)$ (no phage control).

Table 1. Summary of the effects of bacteriophage and phage glycanase on bacterial biofilms grown in batch culture

\begin{tabular}{|c|c|c|c|c|}
\hline \multirow[t]{2}{*}{ Biofilm characteristics } & \multirow[t]{2}{*}{ Treatment } & \multicolumn{3}{|c|}{ Cell number reduction $\left(\mathrm{cm}^{-2}\right)$} \\
\hline & & $0-30 \mathrm{~min}$ & $30-180 \mathrm{~min}$ & Overall $(0-180 \mathrm{~min})$ \\
\hline $\begin{array}{l}\text { Phage-susceptible } \\
\text { bacteria, strain } 53 \mathrm{~b} \text {; } \\
\text { depolymerase- } \\
\text { susceptible EPS }\end{array}$ & $\begin{array}{l}\text { Addition of phage with soluble } \\
\text { depolymerase enzyme }\end{array}$ & $\begin{array}{c}2.61 \times 10^{6}-1.03 \times 10^{4} \\
\quad(253 \text {-fold decline })\end{array}$ & $\begin{array}{c}1.03 \times 10^{4}-1.31 \times 10^{3} \\
(8 \text {-fold decline })\end{array}$ & $\begin{array}{c}2.61 \times 10^{6}-1.31 \times 10^{3} \\
\quad(1992 \text {-fold decline })\end{array}$ \\
\hline $\begin{array}{l}\text { Phage-resistant } \\
\text { bacteria, strain M53b; } \\
\text { depolymerase- } \\
\text { susceptible EPS }\end{array}$ & $\begin{array}{l}\text { Addition of phage with soluble } \\
\text { depolymerase enzyme }\end{array}$ & $\begin{array}{c}1 \cdot 15 \times 10^{6}-3.75 \times 10^{4} \\
(30 \text {-fold decline })\end{array}$ & $\begin{array}{c}3.75 \times 10^{4}-1.87 \times 10^{4} \\
\quad(2 \text {-fold decline })\end{array}$ & $\begin{array}{c}1 \cdot 15 \times 10^{6}-1.87 \times 10^{4} \\
(61 \text {-fold decline })\end{array}$ \\
\hline $\begin{array}{l}\text { Phage-resistant } \\
\text { bacteria, strain Serr; } \\
\text { depolymerase-resistant } \\
\text { EPS }\end{array}$ & $\begin{array}{l}\text { Addition of phage with soluble } \\
\text { depolymerase enzyme }\end{array}$ & $\begin{array}{c}3.2 \times 10^{6}-3.13 \times 10^{6} \\
\text { (negligible decline) }\end{array}$ & $\begin{array}{c}3 \cdot 13 \times 10^{6}-3.08 \times 10^{6} \\
\text { (negligible decline) }\end{array}$ & $\begin{array}{c}3.2 \times 10^{6}-3.08 \times 10^{6} \\
\text { (negligible decline) }\end{array}$ \\
\hline $\begin{array}{l}\text { Phage-susceptible } \\
\text { bacteria, strain } 53 \mathrm{~b} \text {; } \\
\text { depolymerase- } \\
\text { susceptible EPS }\end{array}$ & $\begin{array}{l}\text { Addition of soluble } \\
\text { depolymerase enzyme; no } \\
\text { phage }\end{array}$ & $\begin{array}{c}2.74 \times 10^{6}-4.06 \times 10^{4} \\
\quad(67 \text {-fold decline })\end{array}$ & $\begin{array}{c}4.06 \times 10^{4}-2 \cdot 29 \times 10^{4} \\
(2 \text {-fold decline })\end{array}$ & $\begin{array}{c}2.74 \times 10^{6}-2 \cdot 29 \times 10^{4} \\
\quad(120 \text {-fold decline })\end{array}$ \\
\hline
\end{tabular}




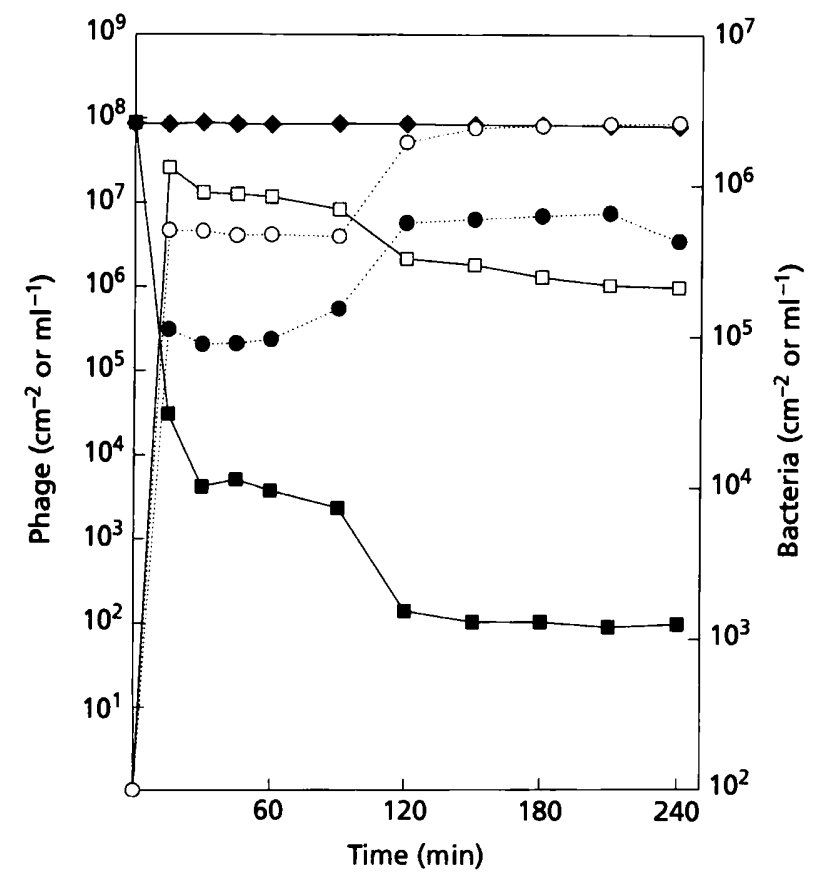

Fig. 3. Infection and degradation of biofilms by bacteriophage. Strain 53b biofilms were grown on coverslips in batch culture and subjected to infection by bacteriophage SF153b. Phage and bacterial counts in the biofilm and in the bulk fluid were monitored. Biofilm bacteria $\left(\mathrm{cm}^{-2}\right) ; 0$, adherent phage $\left(\mathrm{cm}^{-2}\right) ; \square$, planktonic bacteria $\left(\mathrm{ml}^{-1}\right) ; O$, planktonic phage $\left(\mathrm{ml}^{-1}\right) ; \diamond$, biofilm bacteria $\left(\mathrm{cm}^{-2}\right)$ (no phage control).

teriophage. The 'no phage control' showed that the transfer of the glass coverslips from one liquid to another, in the course of the experiment, made little difference to the bacterial counts in the biofilm. The number of bacteriophage and bacteria on the surface of the glass coverslips and in the bulk liquid surrounding the biofilms was monitored. Once bacteria had become infected with phage they were no longer detectable as they lysed before they could produce colonies on agar plates. Therefore, the number of uninfected bacteria was monitored throughout the course of the biofilm infection and degradation. The number of bacteria dropped very rapidly in the first $30 \mathrm{~min}$ after addition of phage, followed by a period when they remained relatively constant (Fig. 3). After approximately $90 \mathrm{~min}$ there was another rapid drop in the number of bacteria. The initial drop in the number of cells was thought to be due to two factors : first, the action of the polysaccharide depolymerase enzyme from the bacteriophage degrading the EPS of the biofilm (this may have caused either a gradual or sudden sloughing off of the biofilm, away from the glass substratum) and second, the infection of a proportion of the biofilm bacterial population. Unfortunately, it was impossible to determine which of the two factors predominated from this experiment alone. After $30 \mathrm{~min}$ the number of uninfected bacteria in the biofilm dropped from $2.61 \times 10^{6}$ to $1.03 \times 10^{4}$ cells $\mathrm{cm}^{-2}$. The bacterial number remained at this level until $90 \mathrm{~min}$ after the initial infection. By $180 \mathrm{~min}$ there had

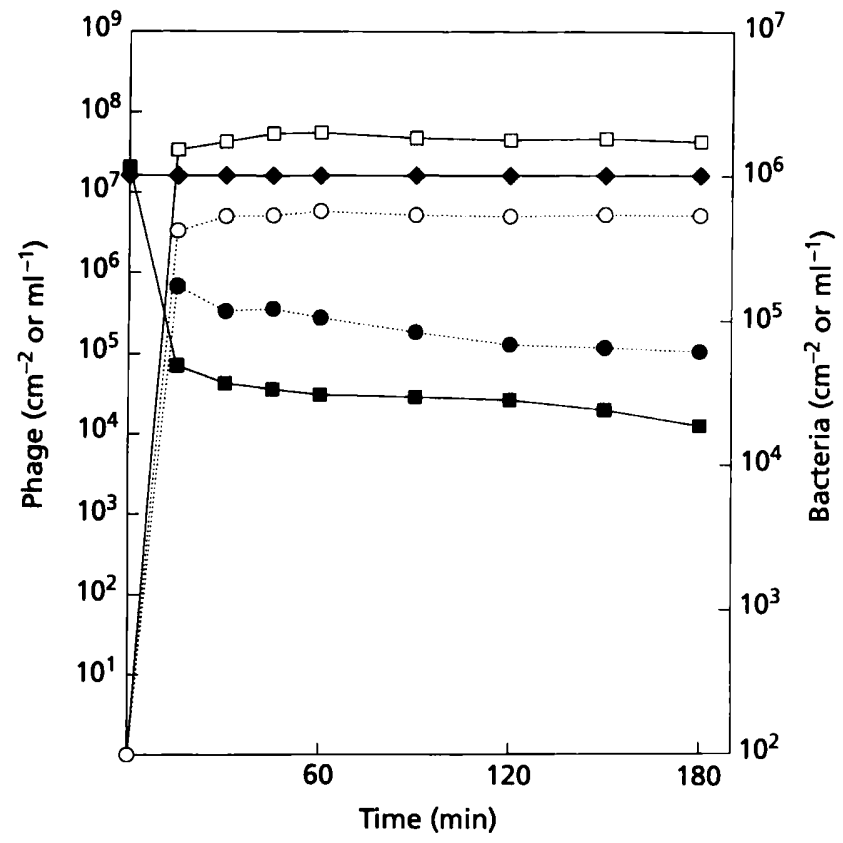

Fig. 4. Effect of phage on phage-resistant biofilms. M53b biofilms were grown on coverslips in batch culture and subjected to bacteriophage SF153b. Phage and bacterial counts in the biofilm and in the bulk fluid were monitored. $\mathbf{a}$, Biofilm bacteria $\left(\mathrm{cm}^{-2}\right) ; 0$, adherent phage $\left(\mathrm{cm}^{-2}\right) ; \square$, planktonic bacteria $\left(\mathrm{ml}^{-1}\right) ; 0$, planktonic phage $\left(\mathrm{ml}^{-1}\right) ; \bullet$, biofilm bacteria $\left(\mathrm{cm}^{-2}\right)$ (no phage control).

been another drop in bacterial counts from $1.03 \times 10^{4}$ to $1 \cdot 31 \times 10^{3} \mathrm{cells}^{-2}$. This was probably due to the lysis of the previously infected cells and the infection of the bacteria that had remained phage-free up to this point. Overall, this gave a decrease in bacterial count, over a period of under $3 \mathrm{~h}$, from approximately $2.61 \times 10^{6}$ to $1.31 \times 10^{3}$ cells cm$~^{-2}$ (almost a 2000 -fold reduction).

The numbers of phage in the biofilm and the bulk fluid was first monitored $15 \mathrm{~min}$ after the phage were first added. Consequently, there may have been many more phage associated with the biofilm initially, but due to biofilm degradation (and sloughing off) the numbers may, after $15 \mathrm{~min}$, have fallen considerably. After $90 \mathrm{~min}$, however, there was an increase in the number of phage within the biofilm which may have been due to lysis of the infected biofilm bacteria and release of phage progeny. It must be remembered that the infected bacteria in the bulk fluid also lysed at this time. Any phage progeny produced may have adhered to the polysaccharide receptors, left as remnants of the biofilm, present on the glass coverslips.

Effect of phage on phage-resistant M53b biofilms. To examine the extent to which the polysaccharide depolymerase of the phage was able to degrade the biofilm, a phage-resistant mutant of strain 53b (M53b) was used (Fig. 4). This mutant still formed a biofilm after $16 \mathrm{~h}$, though the number of bacteria was lower than the wildtype $\left(1.1 \times 10^{6} \mathrm{cells} \mathrm{cm}^{-2}\right.$ for the mutant compared with $2.6 \times 10^{6}$ cells $\mathrm{cm}^{-2}$ for the wild-type). Within the first 


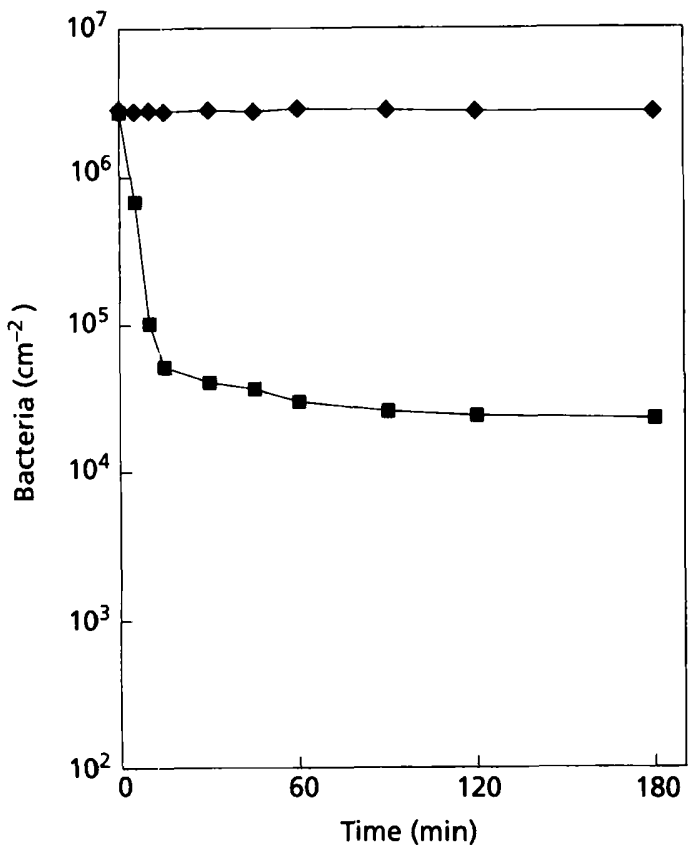

Fig. 5. Infection and degradation of biofilms by phage-free polysaccharide depolymerase. Strain $53 \mathrm{~b}$ biofilms were grown on coverslips in batch culture and subjected to degradation by the polysaccharide depolymerase of phage SF153b. The number of bacteria in the biofilm was monitored. Depolymerase added; $\bullet$, no depolymerase added (control).

30 min after the phage had been added, the bacterial cell count fell from $1.15 \times 10^{6}$ to $3.75 \times 10^{4}$ cells $\mathrm{cm}^{-2}$ due to the action of the polysaccharide depolymerase alone. The secondary drop in the number of bacteria after 90 min seen in the wild-type (phage-susceptible biofilm) was not observed, as there was no phage infection of the biofilm cells and no lysis and secondary infection of the remaining biofilm bacteria by the phage progeny. However, between 30 and $180 \mathrm{~min}$ after addition of phage, the biofilm cell count fell further (from $3.75 \times 10^{4}$ to $1.87 \times 10^{4}$ cells $\mathrm{cm}^{-2}$ ), possibly due to the continued action of the phage polysaccharide depolymerase.

Effect of phage on a phage-resistant Serratia marcescens Serr biofilm with a non-degradable EPS. Strain Serr was not susceptible to infection by bacteriophage SF153b. Neither was its EPS degraded by the polysaccharide depolymerase of SF153b. A biofilm of strain Serr was grown up in batch culture for $16 \mathrm{~h}$ and phage were added in the same way as before. Enumeration of bacteria in the biofilm, at regular intervals over the next $180 \mathrm{~min}$, revealed that the bacterial count did not vary greatly from the initial count of $3.2 \times 10^{6}$ cells cm $\mathrm{cm}^{-2}$ for the duration of the experiment.

Effect of phage-free polysaccharide depolymerase enzyme on a strain $\mathbf{5 3 b}$ biofilm. A further experiment was carried out to determine the effect of phage-free polysaccharide depolymerase on a strain 53b biofilm (Fig. 5). A dramatic drop in bacterial numbers within the biofilm was observed within the first $15 \mathrm{~min}$ (from $2.74 \times 10^{6}$ to
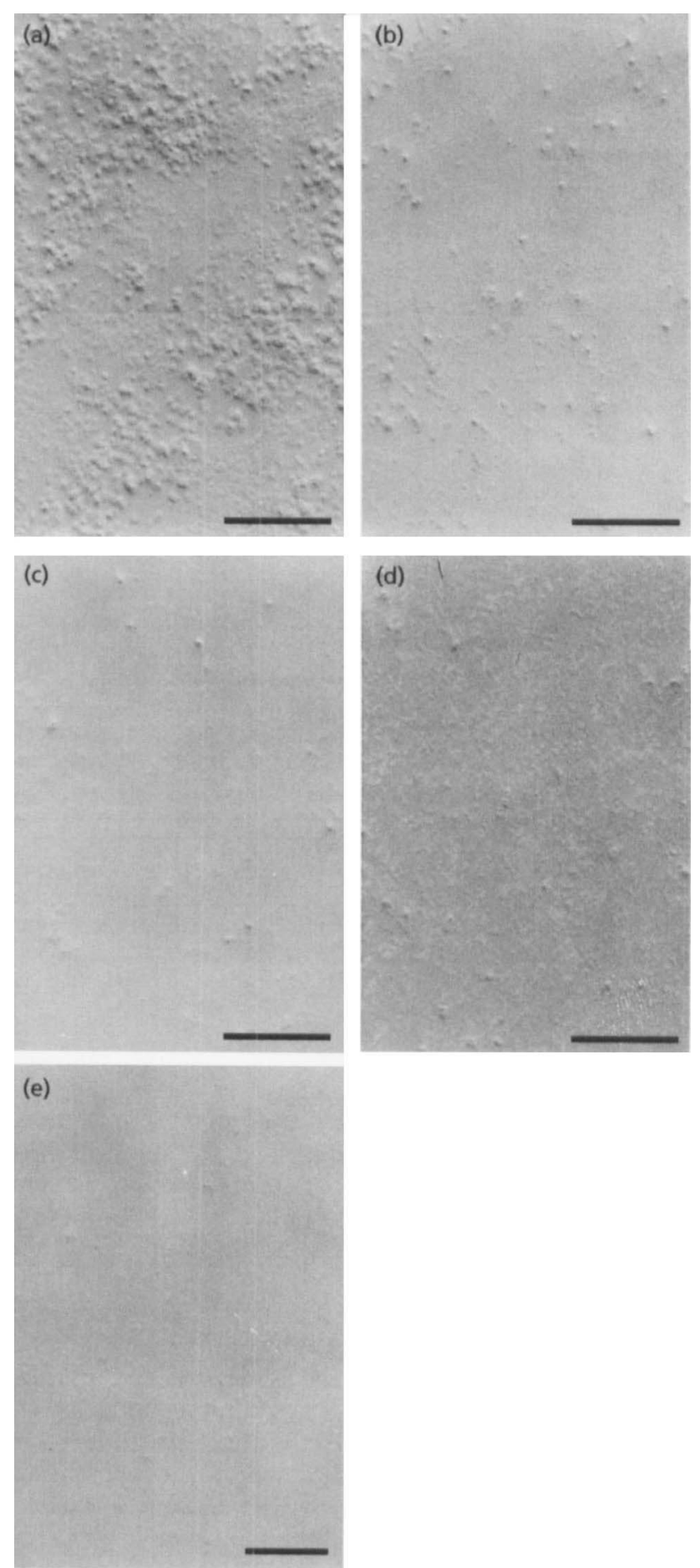

Fig. 6. SEM of biofilm degradation by phage over time. Strain $53 \mathrm{~b}$ biofilms were grown on glass discs in batch culture for $24 \mathrm{~h}$ and then subjected to infection by bacteriophage SF153b. SEM images were taken at 0 (a), 10 (b), 15 (c), 30 (d) and $120 \mathrm{~min}$ (e). $A$ large reduction in the number of bacteria is seen in the first $30 \mathrm{~min}$, presumably due to the action of the polysaccharide depolymerase as the infected cells would not yet have lysed. Bars, $20 \mu \mathrm{m}$.

$5.17 \times 10^{4}$ cells $\mathrm{cm}^{-2}$ ) after which time the numbers remained relatively constant. The number of cells had decreased by a factor of 120 after $180 \mathrm{~min}$. Thus, a 
specific depolymerase enzyme can extensively degrade a bacterial biofilm. The combination of a depolymerase enzyme that can degrade the biofilm EPS and bacteriophage that can lyse the biofilm bacteria results in a powerful method for biofilm destruction whereby both components of the biofilm are disrupted.

However, in a subsequent experiment, a second dose of phage-free polysaccharide depolymerase was added after $60 \mathrm{~min}$. This did not cause any further reduction in the number of cells after the initial drop caused by the first addition of the enzyme. This may suggest that EPS is not the only molecule on the bacterial cell surface causing the adhesion to the surface.

\section{SEM of strain $53 \mathrm{~b}$ biofilm degradation by bacteriophage}

Biofilms of strain 53b were grown up in batch culture, as described above, on $13.5 \mathrm{~mm}$ diameter glass discs instead of $22 \times 22 \mathrm{~mm}$ glass coverslips. The same series of steps was followed for infection of the biofilms with phage as described above. The biofilms were exposed to a phage suspension of $2 \cdot 2 \times 10^{8}$ phage $\mathrm{ml}^{-1}$ for $5 \mathrm{~min}$. Fig. $6(\mathrm{a})$ is an electron micrograph of a control biofilm that had not been exposed to bacteriophage. As can be seen, an extensive biofilm formed on the substratum. Little evidence of the substantial EPS in the biofilm is visible due to the dehydration step required in the processing of the samples for electron microscopy. Fig. $6(\mathrm{~b})$, (c) and (d) show biofilms exposed to bacteriophage after 10, 15 and $30 \mathrm{~min}$, respectively. There were considerably fewer cells visible at $10 \mathrm{~min}$ compared to the control and less after 15 and $30 \mathrm{~min}$. Fig. 6(e) shows the surface of the glass disc after $120 \mathrm{~min}$. Biofilm material was almost completely removed from the substratum and only a few cells can be seen. As this was after the burst time for the phage, some of the visible 'cells' may merely be debris left after lysis.

The numbers of bacteria visible in the electron micrographs were determined and the number $\mathrm{cm}^{-2}$ calculated at each time point (Table 2). The bacterial count derived from the electron micrographs reflected the total number of adherent bacteria, including both phage-infected and uninfected cells and other non-viable cells. The number of uninfected and viable bacteria adhering to the glass surface was determined over time, from batch culture experiments, using plate counts. When these two numbers were compared, for a given time, an estimate could be made of the percentage of the adherent cells which were either infected with phage or non-viable. Table 2 shows that as time went on, the total number of cells and the number of viable cells both fell dramatically. However, the percentage of the remaining adherent cells which were infected or non-viable increased as time proceeded, suggesting that the phage were continually infecting cells even as the biofilm was being degraded. There will have been a certain degree of error in these results due to the different methods used to
Table 2. Bacterial enumeration of phage-infected biofilms using electron micrographs (visible cells) and plate counts (viable cells), suggesting that infection of bacteria by bacteriophage still occurs when the biofilm is degraded

\begin{tabular}{|cccc|}
\hline $\begin{array}{l}\text { Time after } \\
\text { addition of } \\
\text { phage }(\mathrm{min})\end{array}$ & $\begin{array}{c}\text { Visible } \\
\text { bacteria } \\
\left(\mathrm{cm}^{-2}\right)\end{array}$ & $\begin{array}{c}\text { Viable } \\
\text { bacteria } \\
\left(\mathrm{cm}^{-2}\right)\end{array}$ & $\begin{array}{c}\text { Adhering } \\
\text { infected } \\
\text { and/or } \\
\text { non-viable } \\
\text { cells (\%) }\end{array}$ \\
\hline 10 & & & \\
15 & $1.8 \times 10^{6}$ & $1.6 \times 10^{5}$ & 90.4 \\
30 & $6.0 \times 10^{5}$ & $3.0 \times 10^{4}$ & 95.0 \\
120 & $3.75 \times 10^{5}$ & $1.0 \times 10^{4}$ & 97.3 \\
$1.5 \times 10^{5}$ & $1.6 \times 10^{3}$ & 98.9 \\
\hline
\end{tabular}

enumerate the bacteria. Nevertheless, these results have revealed a general trend.

\section{DISCUSSION}

This study has shown that phage can infect and disrupt a biofilm. However certain factors must be considered: first, the susceptibility of the bacteria to the phage and second the ability of the phage-borne glycanase to degrade the biofilm EPS. When only the EPS was degraded, there was still a substantial degree of biofilm removal. Addition of phage to phage-resistant biofilms (M53b biofilm) showed the major role that the phageborne depolymerase played in biofilm removal. This was confirmed when phage-free depolymerase enzyme was added to the phage-susceptible biofilm, again leading to substantial biofilm degradation. Most of the biofilm bacteria had been removed from the substratum, by the action of the depolymerase, long before the phage-infected bacteria had lysed. However, addition of excess depolymerase enzyme after a further $45 \mathrm{~min}$ did not fully remove the biofilm cells. This may be because factors other than EPS are involved in adhesion. These include attachment to the conditioning film and intercellular adhesion through surface appendages or other molecules. If neither the bacteria nor the EPS were affected by the phage then the biofilm remained relatively unaffected (strain Serr biofilm).

The ability of the bacteriophage depolymerase enzyme to degrade EPS produced by both planktonic (Hughes $e t$ al., 1998) and biofilm bacteria suggests that a biofilmspecific EPS is not produced by strain $53 \mathrm{~b}$. Phage depolymerase enzymes are highly specific and subtle changes in EPS composition will prevent them from degrading the polymer. This result agrees with data showing little difference between the chemical composition of EPS produced by biofilm and planktonic bacteria (Hughes et al., 1998).

Assuming that the biofilm bacteria are phage-susceptible and the polymer is readily degraded by the depoly- 
merase, the fate of the biofilm may largely depend upon the number of phage and the specific activity of the enzyme attacking the biofilm (Hughes et al., 1998). An inefficient depolymerase may only allow infection of surface biofilm bacteria, though an efficient enzyme could completely undermine the whole biofilm structure.

In the natural environment it is unlikely that such high phage numbers would be encountered as used in the experiments recorded here. However, in a low energy and turbidity environment, a biofilm could be quickly destroyed by the action of a single phage if it were able to infect and lyse a bacterial cell, multiply and the progeny repeated the process. Biofilm topography and structure may also influence the rate of infection as phage may be able to move through pores and channels to the basal layers where polymer degradation would cause the sloughing off of the whole biofilm (Keevil et al., 1995). Doolittle et al. (1996) followed the infection of E. coli and Pseudomonas aeruginosa biofilms by phage $\mathrm{T} 4$ and E79, respectively. They observed full infection of the relatively thin E. coli biofilm, but the thicker biofilm of $P$. aeruginosa was only infected at the surface and access to the deeper layers was restricted. The high concentration of immobilized bacteria found in biofilms may make them preferred sites for phage reproduction compared to the less accessible bacteria found in liquid culture (Wiggins \& Alexander, 1985). Phage can exist as free phage or as lysogenic phage (prophage) within the bacteria. Consequently, lysogenic phage within biofilm bacteria may revert to the lytic cycle of infection, due to changes in physiology of the host bacteria, resulting in degradation of the biofilm from within.

Bacterial cells in the base of the biofilm may be relatively immune to the action of bacteriophage if they are in a low nutrient or oxygen environment, resulting in a reduced growth rate. The different phenotypic states of bacteria at different levels in a biofilm may lead to the expression of a primary receptor on the cell surface of one member of a species, but not on another in a separate part of the biofilm. These two factors may lead to phage resistance depending on location within the biofilm. EPS synthesis may act as a good method for protecting bacteria against phage in the natural environment. The probability of encountering a phage with a depolymerase specific for the EPS of the bacterium (secondary receptor) and also able to infect at the primary receptor on the cell surface, may not be high (Lindberg, 1977). Mixed biofilm EPS would be highly complex and the interaction of different EPS types may make them almost impossible to degrade by any single phage type. Therefore, the synergistic action of the bacteria in producing EPS may protect the majority of the biofilm occupants from infection by phage. As yet, little is know about mixed biofilms and practically nothing about the degree of mixing of polymers within a biofilm (James et al., 1995). However, Habte \& Alexander (1975) reported that bacteriophage were not responsible for the decline in Xanthomonas campestris bacteria in soil, where the bacteria would probably be present in some form of biofilm. From the results revealed here it would appear that bacteriophage are unlikely to be suitable for removal of contaminating mixed biofilms. However, there may be a practical application if specific phage can be used in a biotechnological environment to help clean fermenters of EPS and remove biofilm cells of a known bacterial strain.

\section{ACKNOWLEDGEMENTS}

We thank Mahendra Gunewardane for technical assistance in construction of the biofilm batch culture equipment. K.A.H. is a recipient of a BBSRC-CASE award.

\section{REFERENCES}

Adams, M. H. \& Park, B. H. (1956). An enzyme produced by a phage-host cell system. II. The properties of the polysaccharide depolymerase. Virology 2, 719-736.

Allison, D. G. (1993). Biofilm associated exopolysaccharides. Microbiol Eur Nov./Dec., 16-19.

Costerton, J. W., Cheng, K.-J., Geesey, G. G., Ladd, T. I., Nickel, J. C., Dasgupta, M. \& Marrie, T. J. (1987). Bacterial biofilms in nature and disease. Annu Rev Microbiol 41, 435-464.

Costerton, J. W., Lewandowski, Z., DeBeer, D., Caldwell, D., Korber, D. \& James, G. (1994). Biofilms, the customized microniche. J Bacteriol 176, 2137-2142.

Doolittle, M. M., Cooney, J. J. \& Caldwell, D. E. (1995). Lytic infection of Escherichia coli biofilms by bacteriophage T4. Can J Microbiol 41, 12-18.

Doolittle, M. M., Cooney, J. J. \& Caldwell, D. E. (1996). Tracing the interactions of bacteriophage using fluorescent and chromogenic probes. J Ind Microbiol 16, 331-341.

Habte, M. \& Alexander, M. (1975). Protozoa as agents responsible for the decline of Xanthomonas campestris in soil. Appl Microbiol 29, 159-164.

Hibma, A. M., Jassim, S. A. A. \& Griffiths, M. W. (1997). Infection and removal of L-forms of Listeria monocytogenes with bred bacteriophage. Int J Food Microbiol 34, 197-207.

Hughes, K. A., Sutherland, I. W. \& Jones, M. v. (1998). Bacteriophage and associated polysaccharide depolymerases - novel tools for study of bacterial biofilms. J Appl Microbiol 85, 583-590.

James, G. A., Beaudette, L. \& Costerton, J. W. (1995). Interspecies bacterial interactions in biofilms. J Ind Microbiol 15, 257-262.

Jass, J. \& Lappin-Scott, H. M. (1992). Practical course on biofilm formation using the Modified Robbins Device. Instructions with $M R D$. University of Exeter: Biofilm Technologies Research Group.

Keevil, C. W., Rogers, J. \& Walker, J. T. (1995). Potable-water biofilms. Microbiol Eur 3, 10-14.

Lindberg, A. A. (1977). Bacterial surface carbohydrates and bacteriophage adsorption. In Surface Carbobydrates of the Prokaryotic Cell, pp. 289-356. Edited by I. W. Sutherland. London: Academic Press.

Ogunseitan, O. A., Sayler, G. S. \& Miller, R. V. (1992). Application of DNA probes to analysis of bacteriophage distribution patterns in the environment. Appl Environ Microbiol 58, 2046-2052.

Reiger-Hug, D. \& Stirm, S. (1981). Comparative study of host capsule depolymerases associated with Klebsiella bacteriophages. Virology 113, 363-378. 
Roy, B., Ackermann, H.-W., Pandian, S., Picard, G. \& Goulet, J. (1993). Biological inactivation of adhering Listeria monocytogenes by listeriaphage and quaternary ammonium compounds. Appl Environ Microbiol 59, 2914-2917.

Sutherland, I. W. (1995). Biofilm-specific polysaccharides-do they exist? In The Life and Death of Biofilms, pp. 103-106. Edited by J. Wimpenny. Cardiff: Bioline.

Sutherland, I. W. \& Wilkinson, J. F. (1965). Depolymerases for bacterial exopolysaccharides obtained from phage infected bacteria. J Gen Microbiol 39, 373-383.
Weiner, R., Langille, S. \& Quintero, E. (1995). Structure, function and immunochemistry of bacterial exopolysaccharides. $J$ Ind Microbiol 15, 339-346.

Wiggins, B. A. \& Alexander, M. (1985). Minimum bacterial density for bacteriophage replication: Implications for significance of bacteriophage in natural ecosystems. Appl Environ Microbiol 49, 19-23.

Received 4 March 1998; revised 15 June 1998; accepted 9 July 1998. 